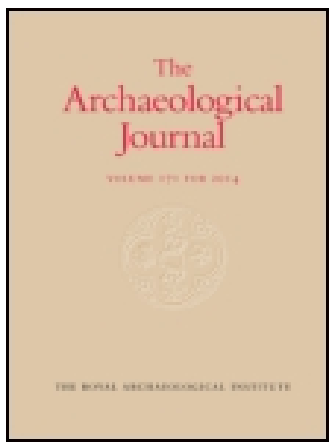

Archaeological Journal

\title{
On The Sepulchral Monument Of A Roman Citizen In The Museum at Caerleon, South Wales
}

\section{H. Bloxam F.S.A.}

To cite this article: M. H. Bloxam F.S.A. (1880) On The Sepulchral Monument Of A Roman Citizen In The Museum at Caerleon, South Wales, Archaeological Journal, 37:1, 55-56, DOI: 10.1080/00665983.1880.10851922

To link to this article: http://dx.doi.org/10.1080/00665983.1880.10851922

册 Published online: 14 Jul 2014.

Submit your article to this journal $₫$

Q View related articles $\sqsubset$ 


\section{ON THE SEPULCHRAL MONUMENT OF A ROMAN CITIZEN}

IN THE MUSEUM AT CAERLEON, SOUTH WALES.

By M. H. BLOXAM, F.S.A.

In the autumn of 1871 the Institute held its annual meeting at Cardiff, South Wales. Un this occasion one of the excursions was to Newport, and to Caerleon, the Roman Station, Isca Silurum. In the Museum of Roman Antiquities at the latter place, my attention was drawn to a sepulchral monument with the effigies in relief, less than life size, and apparently of a Roman citizen and his wife.

The effigy of the latter was so much abraised that it was impossible to make out the details of the dress; not so however with regard to the male effigy, for though abraised in parts, it exhibited very fairly and distinctly features of costume of a peculiar and most interesting character.

$\mathrm{He}$ is represented bareheaded, and attired in the travelling dress or habit of a civilian. The under garment consists of the tunic, tunica, reaching nearly to the ankles; over this, hanging down in front, appears the clavus latus a broad band extending perpendicularly from the neck down the centre in front of the tunic; this differs from the clavus angustus, a narrow band worn over the shoulders and falling down on each side parallel to each other: whilst the outer vestment appeared to me to be the paidóvn, paenula or travelling cloak alluded to by St. Paul,

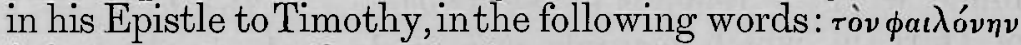

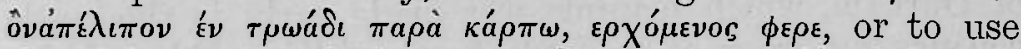
the Vulgate translation, paenulam, quam reliqui Troade apud carpum, veniens affer tecum. This garment, like the South American poncho, had an opening in the middle for the head to go through, and falling in front to the thighs, where it appears rounded, bore no slight resemblance to the casula of a subsequent age. A broad band encircled the paenula about the waist. The right arm and hand are defaced, but seem to have been represented as pouring a libation upon an altar; the left arm, which appears in the sleeve of the tunic, and the hand cross the body obliquely in front. 
It is possible that the drapery over and in front of the left shoulder may represent the chlamys or mantle.

Now, as regards the ecclesiastical vestments of the middle ages, introduced into Britain by Augustine at the close of the sixth century, if we derive the origin from civil costume, we may regard the tunica as the prototype of the alb; the clavus, as the prototype of the stole; and the paidóvn or paenula, as the prototype of the casula or chesible. So we have in this somewhat mutilated effigy a singular series of prototypes of the early ecclesiastical vestments, which I have found in no other Roman sculptured sepulchral monuments I have met with in Britair.

I should observe that it is stated in Dr. Smith's Dictionary of Greek and Roman Antiquities, that the clavus is never represented in works of sculpture, but if I am right in my conjecture, we have it on this.

In such a dress as this it is, I think, fairly probable that the Bishops of the early British Church, who attended at the Council of Arles, held in the fourth century, were arrayed.

I was so impressed with this effigy that I had it purposely photographed, and engraved.

The earliest representation I have met with in this country, in which the ecclesiastical vestments are delineated, and with which the effigy of the Roman citizen at Caerleon may be compared, is that of St. Sextus, Bishop of Rome, in the early part of the third century, whose figure is worked on the Anglo Saxon maniple found with the remains of St. Cuthbert in the Cathedral of Durham, which maniple was made early in the tenth century by order of Aelfred Queen of King Edward the elder. She died A.D. 916.

On this maniple the Bishop, St. Sextus, is represented in the vestments in use in the early part of the tenth century. He appears bareheaded and without the episcopal mitre, which, I think, was not introduced before the twelfth century. $\mathrm{He}$ is vested in the cassock, tunica talaris, alb, stole, maniple, and chesible, the right hand is upheld in front of the breast, whilst hanging over the left hand or wrist is the maniple. This representation is figured in that very learned and interesting work, Raine's St. Cuthbert, p. 33, from which the reduced illustration here subjoined has been taken. 

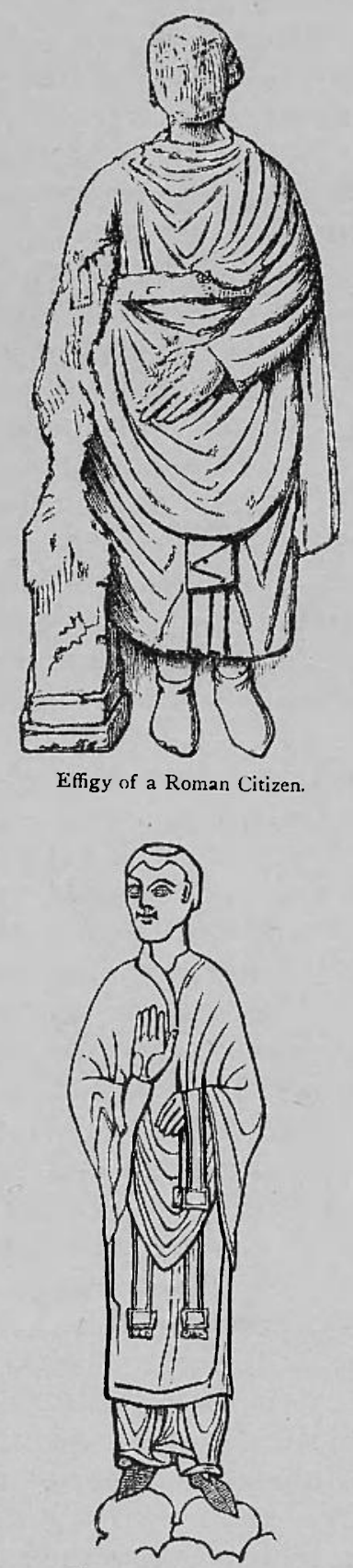

Figure of St. Sextus. 